\title{
A Regional Look at U.S. International Trade
}

\author{
Maximiliano Dvorkin and Hannah G. Shell
}

Economic activity at the state level varies greatly across U.S. regions, with different states specializing in the production of particular goods and services. This heterogeneity in activity informs the geographic distribution of U.S. imports and exports. Using U.S. Census Bureau foreign trade statistics, the authors examine the distribution of U.S. international trade at the state level, controlling for commodities and major trading partners. They find that trade activity varies greatly from state to state and identify two factors affecting this pattern-proximity to a trading partner and geographic location of industries. This analysis is descriptive but can be seen as a step toward understanding the local impact of globalization and asymmetric trade exposure across U.S. regions. (JEL F10, F14, R12)

Federal Reserve Bank of St. Louis Review, First Quarter 2016, 98(1), pp. 17-39.

n the United States, the distribution of economic activity is heterogeneous across space. Different U.S. states tend to specialize in the production of particular goods and services.

This specialization is, in part, a result of available natural resources, such as oil in Texas and Alaska, but also historical and man-made circumstances, such as the location of the auto industry in Michigan or the computer and technology industries in the "Silicon Valley" of California.

In this article, we analyze the interaction between the industry specialization of U.S. states and the geographic distribution of U.S. international trade. We investigate which states export and import the most, which kinds of goods they trade, and who they trade with. Understanding the regional characteristics of production and trade is important for gauging, for example, the effects of an increase in Chinese imports on Californian labor markets or the effects of a European recession on the auto industry in Michigan. Our analysis is descriptive but can be seen as a step toward understanding the local impact of globalization and asymmetric trade exposure across U.S. regions. ${ }^{1}$

For this analysis, we use import and export data at the national and state levels for 2014 from U.S. Census Bureau foreign trade statistics. We classify the goods according to the threedigit North American Industry Classification System (NAICS) and focus on the top-five

Maximiliano Dvorkin is an economist and Hannah G. Shell is a senior research associate at the Federal Reserve Bank of St. Louis.

(c) 2016, Federal Reserve Bank of St. Louis. The views expressed in this article are those of the author(s) and do not necessarily reflect the views of the Federal Reserve System, the Board of Governors, or the regional Federal Reserve Banks. Articles may be reprinted, reproduced, published, distributed, displayed, and transmitted in their entirety if copyright notice, author name(s), and full citation are included. Abstracts, synopses, and other derivative works may be made only with prior written permission of the Federal Reserve Bank of St. Louis. 


\section{Dvorkin and Shell}

traded commodities, which account for roughly 58 percent of imports and exports. For the United States, the top-four exported commodities are also the top-four imported, with a fifth for each being energy related.

Standard theories of international trade, such as the Ricardian model or the HeckscherOhlin model, suggest that countries or regions will produce and export goods for which they have a comparative advantage and import the rest. ${ }^{2}$ Patterns observed in U.S. data, however, are at odds with these theories of trade. Moreover, a similar pattern holds for U.S. trading partners-the top exporters are also the top importers. This article analyzes the top-four U.S. trading partners, Canada, Mexico, the European Union, (EU) and China, which account for roughly 60 percent of exports and 64 percent of imports. ${ }^{3}$

A newer generation of trade models emphasizes product differentiation and variation in consumer tastes to reconcile the fact that a substantial volume of trade across countries is intra-industry trade. ${ }^{4,5}$ The intuition is simple: For example, the United States both exports and imports cars, as some consumers prefer to buy a Ford, while others a Mercedes-Benz. A European consumer's Ford purchase counts as a U.S. export, while a U.S. consumer's Mercedes-Benz purchase counts as a U.S. import. The same analogy is easily applied to purchases from Boeing (a U.S. aircraft company) and Airbus (a European aircraft company).

In addition, we find large, regional dispersion in the patterns of international trade, which is partly explained by proximity to trading partners. For example, the states that trade with Canada the most are the northern states bordering Canada. ${ }^{6}$ This finding is consistent with gravity models of international trade, in which proximity (broadly defined to capture distance) and transportation costs are important determinants of trade. ${ }^{7}$

Earlier versions of the gravity models of trade were mostly empirical and drew an analogy to Newton's law of universal gravitation-objects with larger mass or closer to each other will have larger gravitational pull between them. In economic terms, countries or regions with higher incomes or close to each other-close geographically and/or having lower tariffs or similar lower barriers to trade-should see larger volumes of trade between them. Several microfounded models of trade have been developed to account for gravity relationships. ${ }^{8}$

Overall, our study identifies two main forces at play that explain the regional patterns of trade, which can be easily missed using a more aggregate approach. As discussed, proximity to a trading partner is an important determinant of trade. However, the geographic location of industries, perhaps due to regional comparative advantage, also affects the exposure of U.S. states to international trade. For example, computer and electronic products are primarily imported and exported by the western states. Proximity to a major trading partner affects this pattern only mildly. So, while the northern states trade more with Canada overall, presumably due to proximity, California and Texas provide a larger share of U.S. computer and electronic products exported to Canada.

This article is organized as follows. The next section analyzes total U.S. imports and exports by major trading partner. The third section examines U.S. trade of commodities with the world and by major trading partner. The fourth section analyzes state trade by major U.S. trading partner and commodity. The final section discusses some caveats in the data and concludes. 


\section{TOTAL U.S. IMPORTS AND EXPORTS}

We start our analysis by looking at the value of total exports and imports by state. We first focus on total international trade and then analyze state trade by major U.S. trading partner.

Trade data for our analysis are from U.S. Census Bureau foreign trade statistics. We use state and national annual imports and exports of goods by trading partner and commodity from the USA Trade Online database. The commodities are classified at the three-digit NAICS level. We use 2014 data only, the most recent full year of data available. We treat the District of Columbia (D.C.) as one state but do not include U.S. territories or possessions. To facilitate state-level comparisons, we divide each state's total import and export values, respectively, by the state's population in 2014 to calculate per capita values. ${ }^{9}$ The Census data provide a geographic distribution of import and exports of goods only. Although international trade in services is a large component of total U.S. trade, the lack of a geographic distribution prevents us from including services in our analysis.

\section{Total International U.S. Imports and Exports}

In 2014, the U.S. exported \$1.6 trillion of goods and imported \$2.3 trillion. Figure 1 shows the distribution of per capita imports (bottom map) and exports (top map) across the 50 states and D.C. The darkest color is the top 25 percent (first quartile) and the lightest is the bottom 25 percent (last quartile). As the figure shows, imports and exports vary quite substantially across states. On average, states exported $\$ 4,276$ per person in 2014 . The biggest per capita exporter in 2014 was Louisiana, at $\$ 13,939$, followed closely by Washington, at $\$ 12,822$. The smallest was Hawaii, at $\$ 1,019 .{ }^{10}$ In terms of total U.S. exports (not per capita), Texas exported the most overall, $\$ 288$ billion, or 18 percent of the total, while D.C. exported the least.

As shown in Figure 1, the states that import the most do not necessarily export the most. Nonetheless, imports and exports are highly correlated. The per capita average of imports across all states was $\$ 5,757$ in 2014 . New Jersey, Louisiana, and Michigan imported the most per capita: $\$ 14,137, \$ 12,389$, and $\$ 12,385$, respectively. New Mexico imported the least, only $\$ 1,072$ per capita. In terms of total U.S. imports, California imported the most, around $\$ 403$ billion, or 17 percent of the total; Texas was next with $\$ 302$ billion, or 13 percent of the total; and South Dakota imported the least.

\section{Total U.S. Imports and Exports by Major Trading Partner}

Table 1 shows the annual import and export values for trade in goods between the United States and several selected countries and areas in 2014. Canada was the biggest recipient of U.S. exports, at about $\$ 312$ billion, followed by the EU, Mexico, and China. ${ }^{11}$ Overall, these four trading partners accounted for close to 60 percent of total U.S. exports and 64 percent of total U.S. imports. Most U.S. imports in 2014 came from China, totaling about $\$ 467$ billion, followed by the EU, Canada, and Mexico. Japan was the next-largest trading partner for imports and exports, although the trade pattern was imbalanced: In 2014, the U.S. imported twice the amount of goods from Japan as it exported to Japan. 


\section{Figure 1}

\section{U.S. Exports and Imports (2014)}
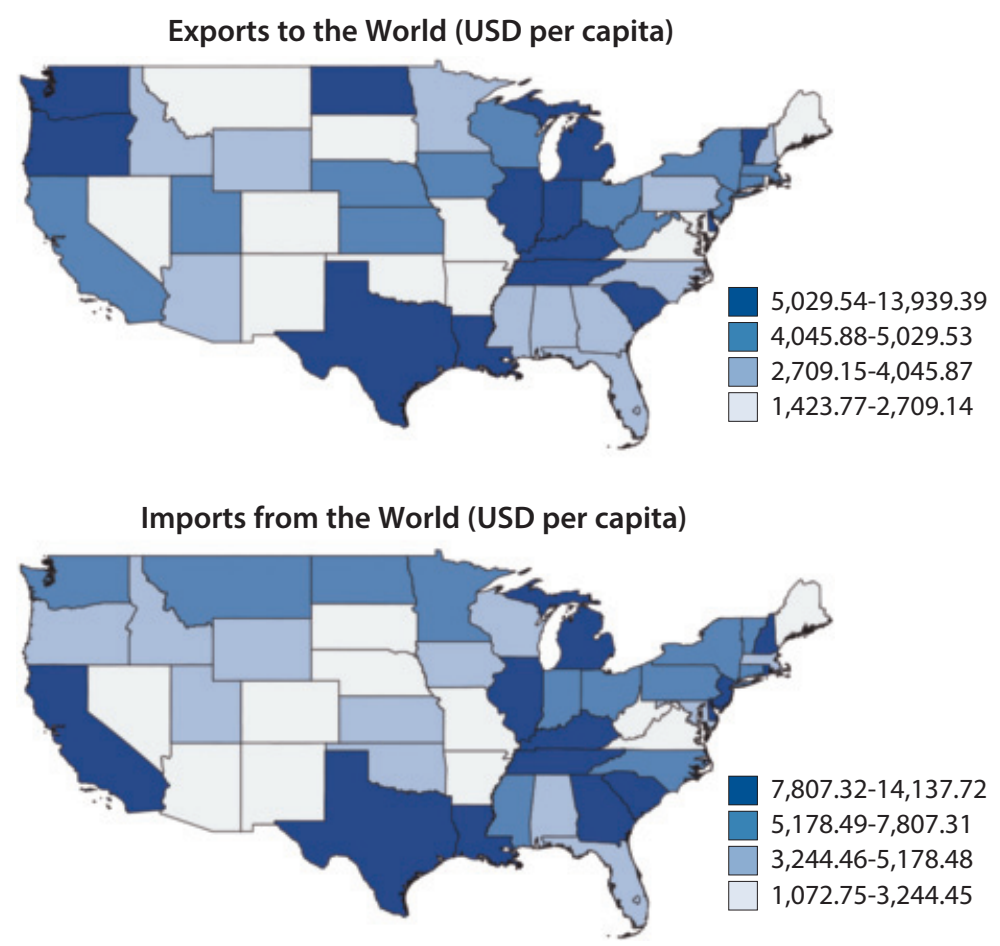

SOURCE: U.S. Census Bureau foreign trade statistics.

Similar to the variation in state-level imports and exports, certain states trade more with certain trading partners. Figures 2 through 5 show the per capita spatial distribution of U.S. exports (top maps) and imports (bottom maps) in 2014 by the four largest bilateral trading partners listed previously.

Canada. As shown in Figure 2, U.S. trade with Canada exhibits a clear spatial pattern in 2014. In fact, there is a positive correlation between the value of per capita trade with Canada and a state's proximity to Canada. On average, states exported $\$ 972$ per capita to Canada and imported $\$ 1,295$. The five states that imported or exported, respectively, the most per capita to Canada in 2014 are all in the northern half of the United States. The biggest exporter per capita was North Dakota, at $\$ 5,881$, while the biggest importer per capita was Vermont, at $\$ 5,937$. In terms of total U.S. trade with Canada in 2014, Michigan imported the most, $\$ 49$ billion, or 14 percent of the total, and Texas exported the most, $\$ 31$ billion, or 10 percent of the total.

China. Figure 3 shows state per capita trade with China in 2014. On average, states exported $\$ 387$ per capita to China and imported $\$ 929$. Washington exported the most, $\$ 2,929$ per capita, while Tennessee imported the most, $\$ 3,868$ per capita, followed closely by California 


\section{Table 1}

U.S. Trade in Goods by Selected Countries and Groups (2014)

\begin{tabular}{llll}
\multicolumn{1}{c}{ Exports (USD millions) } & \multicolumn{2}{c}{ Imports (USD millions) } \\
\hline Canada & 312,421 & China & 466,755 \\
\hline European Union & 276,143 & European Union & 418,201 \\
\hline Mexico & 240,249 & Canada & 347,798 \\
\hline China & 123,676 & Mexico & 294,074 \\
\hline Japan & 66,827 & Japan & 134,004 \\
\hline United Kingdom & 53,823 & Germany & 123,260 \\
\hline Germany & 49,363 & Korea, South & 69,518 \\
\hline Korea, South & 44,471 & United Kingdom & 54,392 \\
\hline Netherlands & 43,075 & Saudi Arabia & 47,041 \\
\hline Brazil & 42,429 & France & 46,874 \\
\hline Hong Kong & 40,858 & India & 45,244 \\
\hline Belgium & Italy & 42,115 \\
\hline France & 34,790 & Taiwan & 40,582 \\
\hline Singapore & 31,301 & Ireland & 33,956 \\
\hline Taiwan & 30,237 & Switzerland & 31,191 \\
\hline Australia & 26,670 & Vietnam & 30,589 \\
Switzerland & 26,582 & Brazil & 30,537 \\
\hline United Arab Emirates & 22,176 & Malaysia & 30,420 \\
\hline India & 22,069 & Venezuela & 30,219 \\
\hline Colombia & 21,608 & Thailand & 27,123
\end{tabular}

SOURCE: U.S. Census Bureau, U.S. International Trade in Goods and Services, FT900 Exhibit 13, Not Seasonally Adjusted, Census Basis.

at $\$ 3,548$ per capita. In terms of total U.S. trade with China in 2014, California imported the most, $\$ 137$ billion, or almost 30 percent of the total, while Washington exported the most, $\$ 20$ billion, or 17 percent of the total.

European Union. As shown in Figure 4, in general, EU imports in 2014 appear to be more concentrated in northeastern states. This concentration could be because of geographic proximity or greater demand for EU imports due to cultural similarity with the EU. On average, states exported $\$ 754$ per capita to the EU and imported $\$ 1,167$. Louisiana was the biggest per capita exporter, at $\$ 2,446$, while Delaware was the biggest per capita importer, at $\$ 4,631$. In terms of total U.S. trade with the EU, New Jersey and New York imported $\$ 36$ and $\$ 33$ billion, respectively, together receiving 17 percent of the total. Texas exported the most, $\$ 30$ billion, or 11 percent of total U.S. exports to the EU.

Mexico. As shown in Figure 5, U.S. trade with Mexico in 2014 shows concentration among southern states closer to the Mexican border and Midwestern states with large agricultural industries. On average, states exported \$454 per capita from Mexico and imported $\$ 571$. Texas exported the most to Mexico, \$3,804 per capita, while Michigan imported the 


\section{Dvorkin and Shell}

\section{Figure 2}

\section{U.S. Exports to and Imports from Canada (2014)}
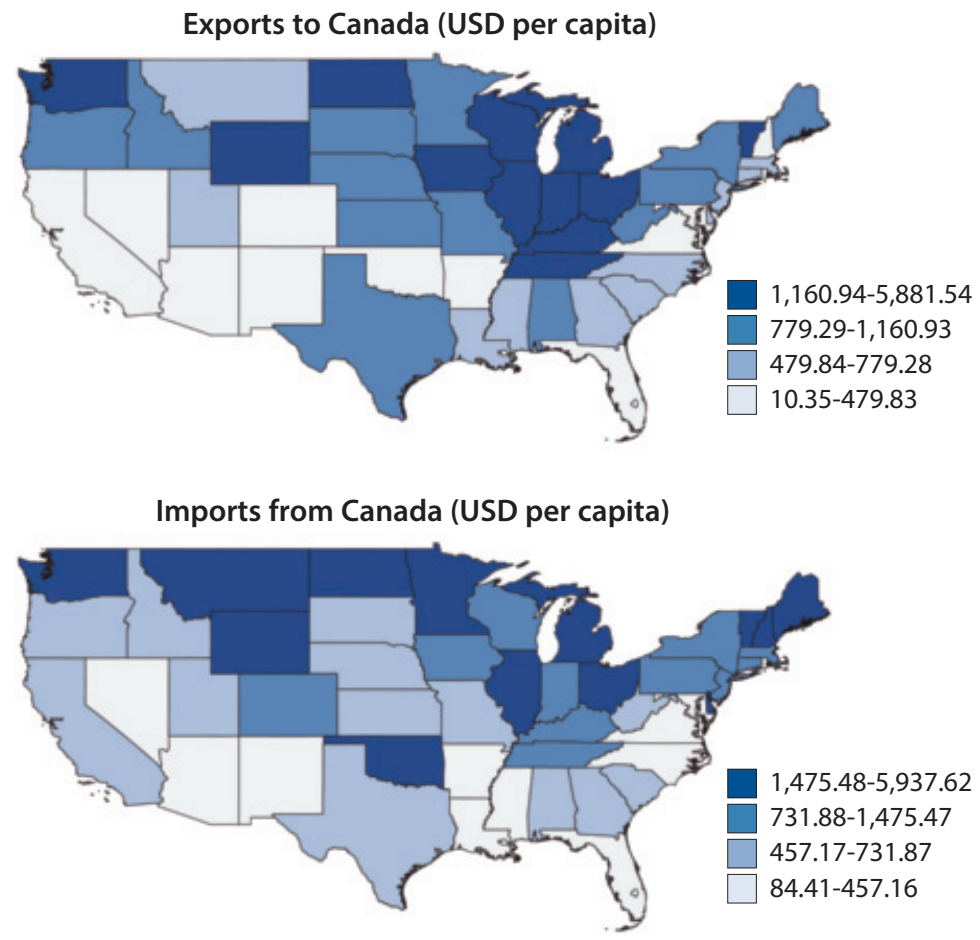

SOURCE: U.S. Census Bureau foreign trade statistics.

most, $\$ 4,286$ per capita. In terms of total U.S. trade with Mexico in 2014, Texas was the biggest trading partner, exporting $\$ 102$ billion and importing $\$ 90$ billion, or 43 percent of total exports to Mexico and 31 percent of total imports from Mexico. ${ }^{12}$ 
Figure 3

U.S. Exports to and Imports from China (2014)

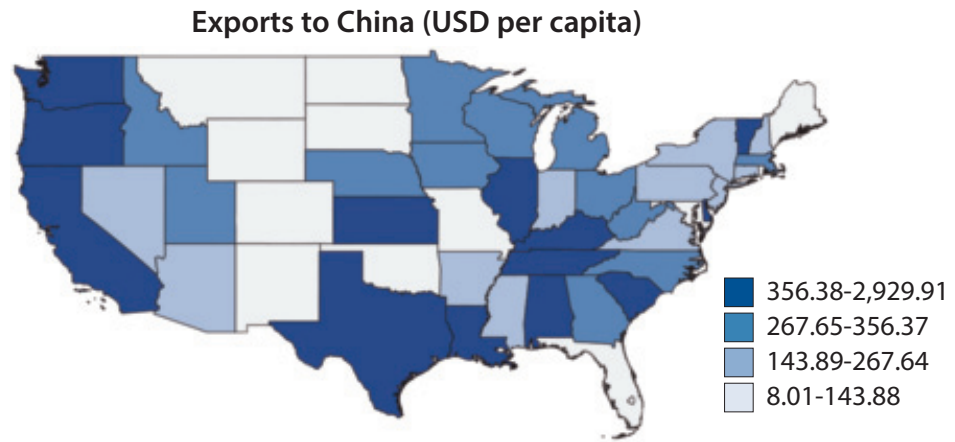

Imports from China (USD per capita)

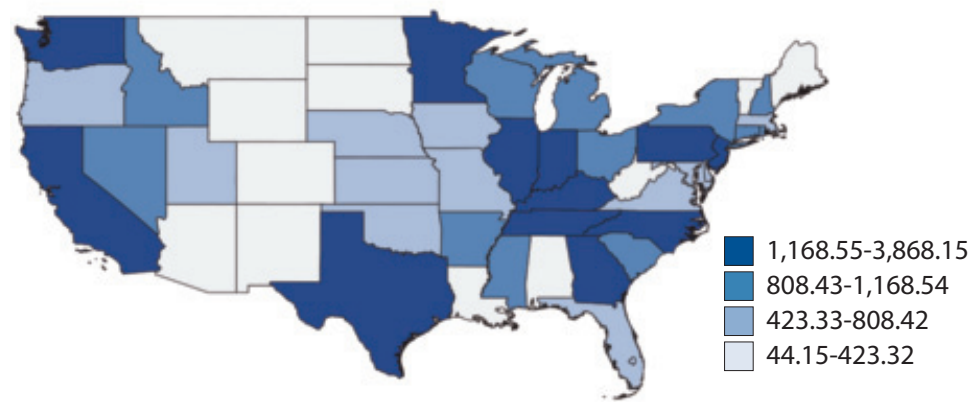

SOURCE: U.S. Census Bureau foreign trade statistics. 


\section{Dvorkin and Shell}

\section{Figure 4}

\section{U.S. Exports to and Imports from the European Union (2014)}

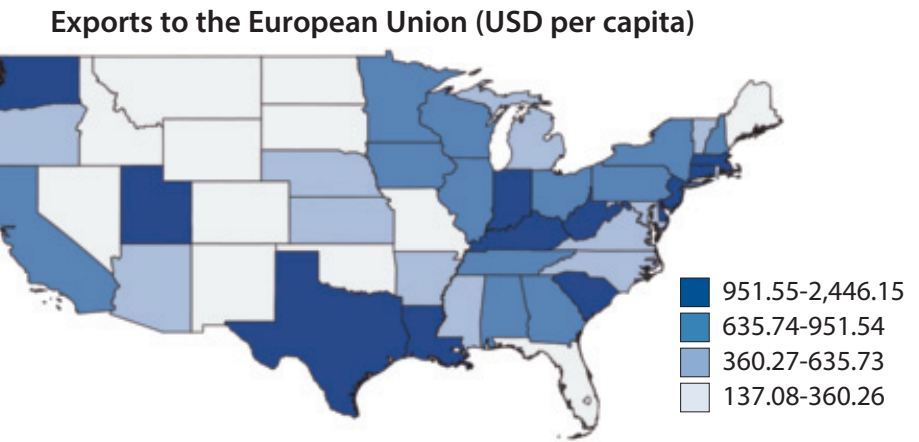

Imports from the European Union (USD per capita)

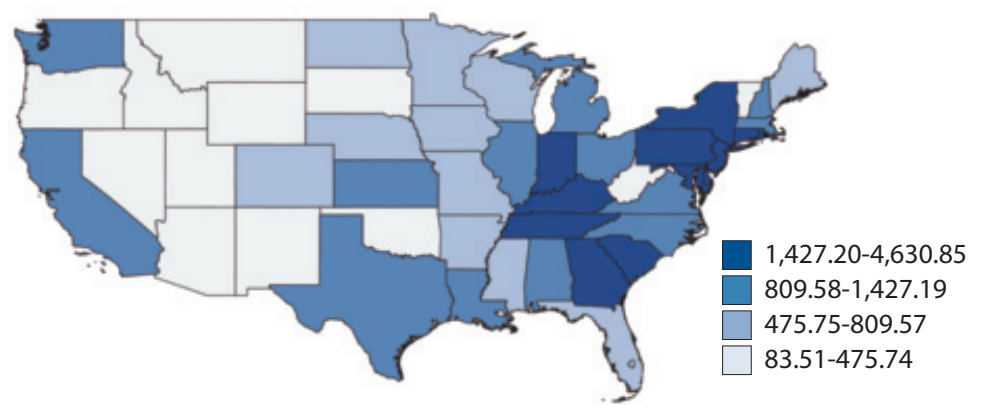

SOURCE: U.S. Census Bureau foreign trade statistics. 
Figure 5

U.S. Exports to and Imports from Mexico (2014)
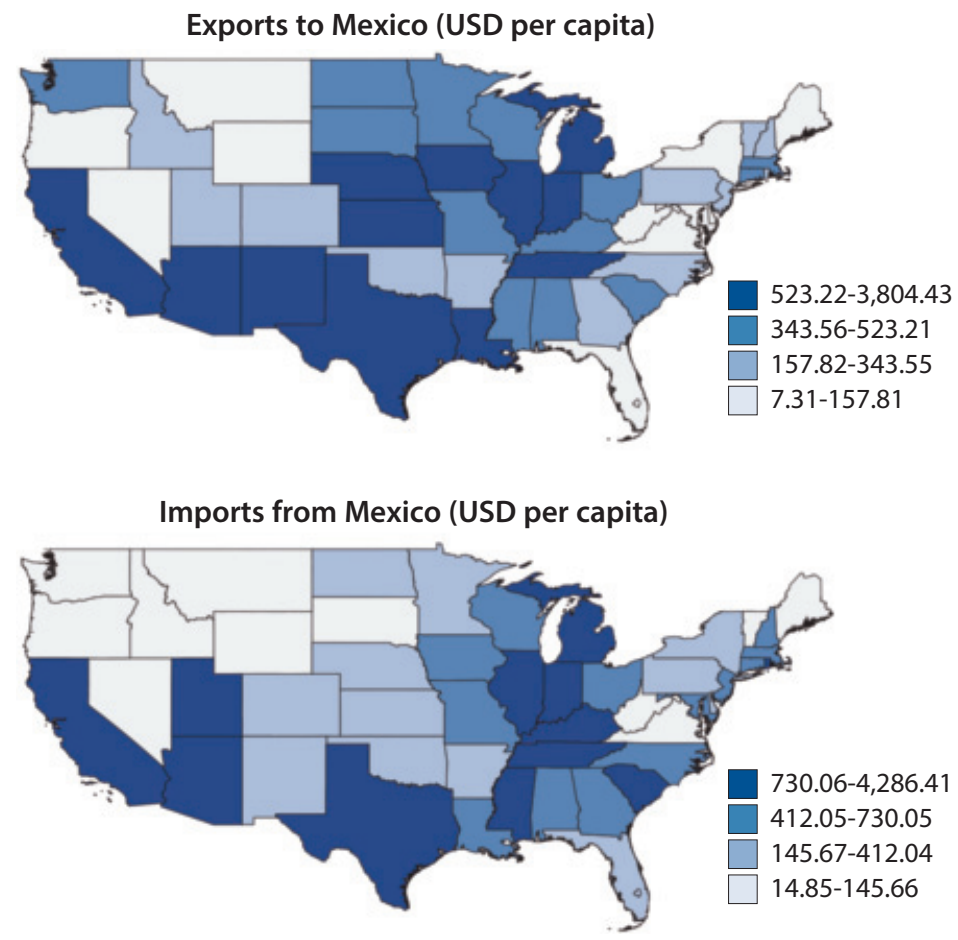

SOURCE: U.S. Census Bureau foreign trade statistics. 


\section{Table 2}

\section{U.S Imports of Goods for Selected NAICS-Based Product Codes (2014)}

\begin{tabular}{lc} 
Product code & Imports (USD millions) \\
\hline Computer and electronic products & 365,805 \\
Transportation equipment & 355,720 \\
Oil and gas & 263,230 \\
Chemicals & 205,668 \\
Machinery, except electrical & 160,847 \\
Miscellaneous manufactured commodities & 111,422 \\
Primary metal manufacturing & 101,165 \\
Electrical equipment, appliances, and components & 99,793 \\
Apparel and accessories & 86,613 \\
Petroleum and coal products & 81,976 \\
Fabricated metal products, NESOI & 66,199 \\
Goods returned & 60,387 \\
Food and kindred products & 57,130 \\
Plastics and rubber products & 49,645 \\
Other & 282,086 \\
NOTE: NESOI, not elsewhere specified or included. & \\
SOURCE: U.S. Census Bureau foreign trade statistics. &
\end{tabular}

\section{U.S. IMPORTS AND EXPORTS BY MAJOR COMMODITY}

In this section, we use three-digit NAICS product codes to examine which commodities make up the majority of U.S. imports and exports.

Tables 2 and 3 show imports and exports, respectively, for the 15 most-traded commodity groups in 2014. The biggest U.S. import was computer and electronic products, which include computers and peripherals; communication, audio, and video equipment; and navigational, control, and electro-medical instruments. In 2014, the United States imported about \$366 billion of these goods, or 16 percent of total U.S. imports. Transportation equipment, which includes automobiles, trucks, trains, boats, airplanes, and their parts, was the second-largest U.S. import in 2014, at more than $\$ 355$ billion, or 15 percent of total U.S. imports. Oil and gas, chemicals, and machinery (excluding electrical) round out the top-five imports. Oil and gas includes only crude petroleum and natural gas and accounted for $\$ 263$ billion of U.S. imports, followed by chemicals at over $\$ 205$ billion. Chemicals include pesticides and fertilizers; pharmaceutical products; paints and adhesives; soap and cleaning products; and raw plastics, resins, and rubber. Finally, U.S. imports of machinery totaled about $\$ 161$ billion. Machinery includes goods for ventilation, heating, and air conditioning (both for consumers and companies); power tools; and industrial equipment. These five categories together made up about 58 percent of total U.S. imports in 2014. 


\section{Table 3}

\section{U.S Exports of Goods for Selected NAICS-Based Product Codes (2014)}

\begin{tabular}{lc} 
Product code & Exports (USD millions) \\
\hline Transportation equipment & 273,637 \\
Computer and electronic products & 209,058 \\
\hline Chemicals & 200,222 \\
Machinery, except electrical & 152,560 \\
\hline Petroleum and coal products & 116,935 \\
Miscellaneous manufactured commodities & 81,914 \\
\hline Agricultural products & 72,927 \\
Food and kindred products & 70,708 \\
\hline Primary metal manufacturing & 64,040 \\
Electrical equipment, appliances, and components & 60,585 \\
Fabricated metal products, NESOI & 49,245 \\
Special classification provisions, NESOI & 43,801 \\
Plastics and rubber products & 33,877 \\
\hline Oil and gas & 29,766 \\
\hline Other & 161,257 \\
\hline NOTE: NESOI, not elsewhere specified or included. & \\
SOURCE: U.S. Census Bureau foreign trade statistics. &
\end{tabular}

In terms of total U.S. exports in 2014, transportation equipment was the largest exported commodity, at $\$ 273$ billion, or about 17 percent of the total. Four of the top-five exported commodities were the same as those imported, just in a slightly different order. The remaining top commodity for each was energy related: More oil and gas was imported and more petroleum and coal products were exported. Petroleum and coal products include refined petroleum products, such as gasoline, lubricating oils, and asphalt, and totaled \$117 billion of U.S. exports in 2014. Another major U.S. import that is not a major U.S. export was apparel and accessories. Instead, in 2014 the United States exported more agricultural products.

Figure 6 shows the values of the top-five U.S. imports in 2014 from the four major trading partners. With the exception of oil and gas, the four trading partners provided around 70 percent of total U.S. imports for each of the commodities. For oil and gas, they provided 48 percent. The U.S. imported the most transportation equipment, which includes cars, from Canada, Mexico, and the EU, with Mexico being the largest source, at $\$ 89$ billion, or 25 percent of total transportation equipment imported. Nearly half (46 percent) of U.S. imports of computer and electronic products came from China and totaled $\$ 167$ billion. The most U.S. imports of chemicals came from the EU (44 percent) and totaled $\$ 90$ billion. The most U.S. imports of oil and gas (37 percent) came from Canada and totaled \$97 billion. China and the EU export almost no oil and gas to the United States, which is no surprise given that these countries produce little of these commodities and are net importers themselves. U.S. imports of machinery 


\section{Dvorkin and Shell}

\section{Figure 6}

Top U.S. Imports by Trading Partner (2014)

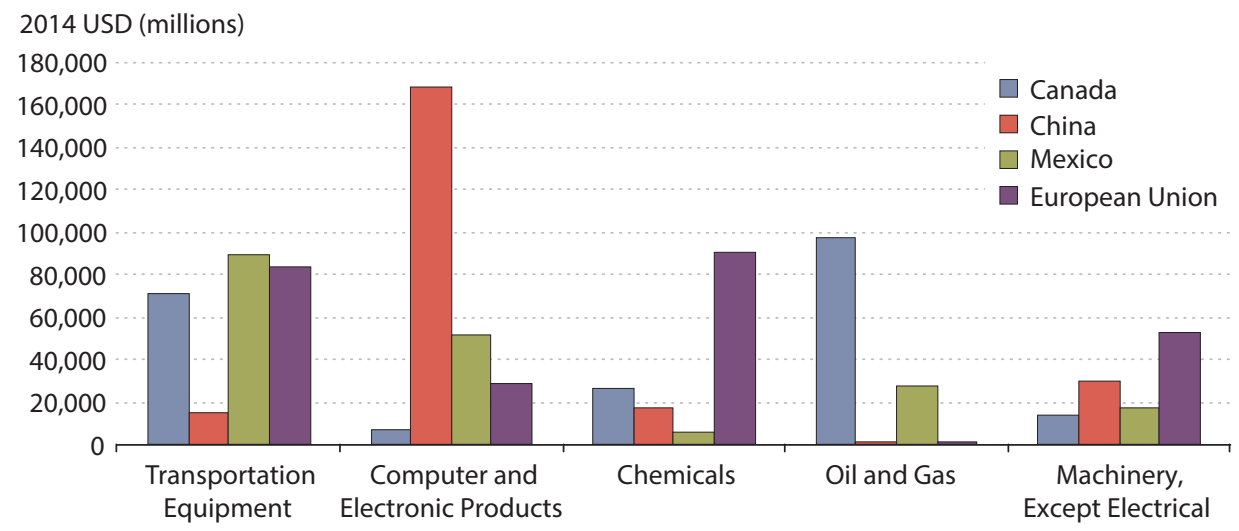

SOURCE: U.S. Census Bureau foreign trade statistics.

Figure 7

Top U.S. Exports by Trading Partner (2014)

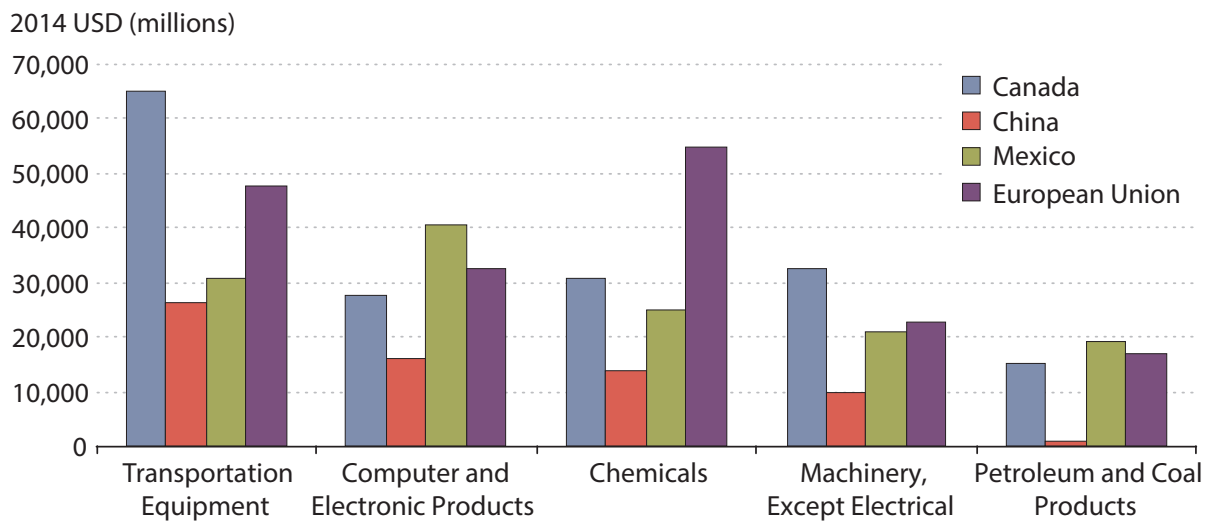

SOURCE: U.S. Census Bureau foreign trade statistics.

came mostly from the EU and China, $\$ 52$ billion (33 percent) and $\$ 29$ billion (18 percent), respectively.

As shown in Figure 7, U.S. exports in 2014 were more evenly spread among the trading partners than imports. The top-four trading partners together received about 60 percent of each of the top-four exported commodities and 45 percent of the fifth-petroleum and coal products. Canada received the most U.S. exports of transportation equipment, $\$ 65$ billion (24 percent), followed by the EU at $\$ 47$ billion (13 percent). The most U.S. exports of com- 
puter and electronic products went to Mexico, $\$ 40$ billion (19 percent). Similar to U.S. imports of chemicals, the EU received the most U.S. exports of chemicals, \$54 billion (27 percent). Canada also received the most U.S. exports of machinery, $\$ 32$ billion (21 percent). Lastly, Mexico received the most U.S. exports of petroleum and coal products, $\$ 19$ billion (16 percent).

\section{STATE-LEVEL IMPORTS AND EXPORTS BY COMMODITY AND TRADING PARTNER}

We have described U.S. trade in terms of major trading partners (Canada, China, Mexico, and the EU) and identified the major traded commodities (computer and electronic products, transportation equipment, chemicals, and machinery).

Our state-level analysis by major trading partner shows that trade volume seems to be influenced by proximity. However, aggregation may mask some important heterogeneity due to the particular geographic distribution of industries. For example, given the large production of automobiles in Michigan, it is expected that exports of automobiles (or their parts) from Michigan and imports of automobiles (or their parts) to Michigan will be large.

It is important to highlight that a sizable fraction of imports are intermediate goods. ${ }^{13}$ Therefore, the geographic location of industries will affect the geographic distribution of imports according to the inputs they demand. To identify which goods individual states trade the most with which major U.S. bilateral trading partners, Figures 8 through 15 show for each commodity per capita state imports (the first figure for each) and exports (the second figure for each) in 2014 by trading partner and for the world.

\section{Chemicals}

Figure 8. In general, states in the eastern half of the United States and the Rust Belt imported the most chemicals per capita. Delaware and Indiana were the biggest per capita importers of chemicals, at $\$ 4,078$ and $\$ 2,010$, respectively. As mentioned, most U.S. imports of chemicals came from the EU, with many states importing the most chemicals per capita from the EU; however, quite a few northern states such as Wyoming, Montana, and Oregon imported most of their chemicals from Canada. Delaware imported more chemicals per capita from the EU than any other state, at $\$ 3,612$. The biggest per capita importers of chemicals from Mexico, Canada, and China were West Virginia, New Jersey, and North Dakota, respectively.

Figure 9. In 2014, states exporting chemicals were more geographically spread out than those importing chemicals. The biggest per capita exporters of chemicals were Delaware, Louisiana, and Texas, at over $\$ 1,700$ each. The EU received the most U.S. exports of chemicals overall, and this relationship mostly holds at the state level: Nearly every state exports more chemicals to the EU than any other trading partner. A few states such as Iowa, New Jersey, and Ohio exported more chemicals to Canada, and New Mexico, Arizona, and Texas exported more to Mexico. Oregon and Hawaii are the only states that sent the majority of their chemical exports to China. Not surprisingly, Delaware was the biggest U.S. exporter of chemicals to China and the EU, Texas was to Mexico, and North Dakota was to Canada. 


\section{Dvorkin and Shell}

\section{Figure 8}

\section{U.S. Imports of Chemicals from the World and by Trading Partner (2014)}

Imports from the World (USD per capita)

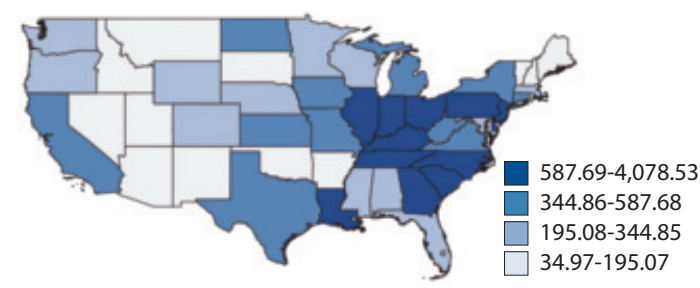

Imports from Mexico (USD per capita)

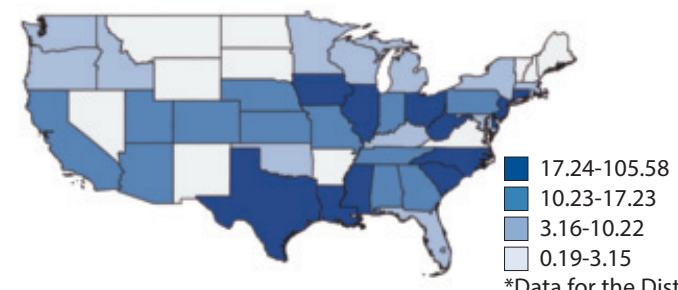

*Data for the District of Columbia are not available.
Imports from Canada (USD per capita)

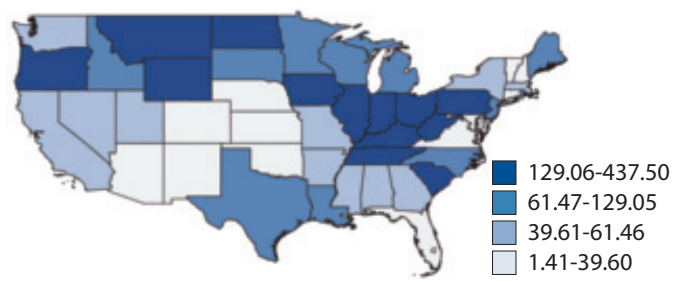

Imports from the European Union (USD per capita)

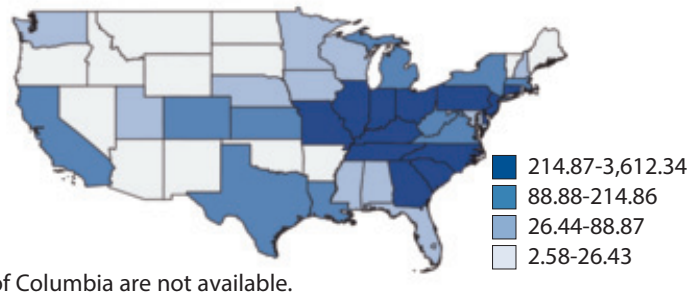

Imports from China (USD per capita)

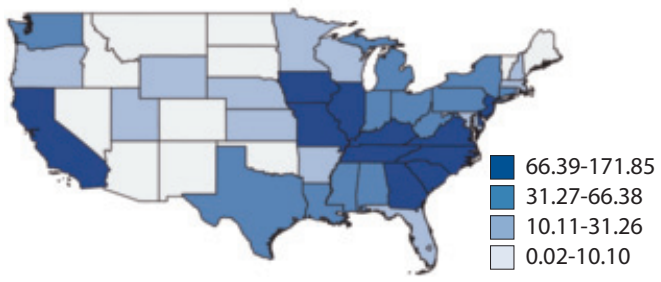

SOURCE: U.S. Census Bureau foreign trade statistics.

\section{Computer and Electronic Products}

Figure 10. As stated, computer and electronic products were overall the biggest U.S. import in 2014. Relative to states importing chemicals, states importing computer and electronic products were more spread out geographically, with slight concentration in the western United States (Figure 10). On average, in 2014, states imported $\$ 700$ per capita of computer and electronic products. The biggest per capita importers were Tennessee, California, and Texas, at over $\$ 2,400$ each. Most states imported more of their computer and electronic products from China than any other country, while a few states, such as Delaware and Connecticut, imported more from the EU and Colorado imported more from Mexico. Vermont was the biggest per capita state importer of computer and electronic products from Canada, while Tennessee was the biggest from China and Minnesota from the EU. As expected, Texas was the biggest per capita state importer of computer and electronic products from Mexico.

Figure 11. In contrast to imports, U.S. exports of computer and electronic products in 2014 were more geographically concentrated in western states. Almost all of the top per capita 


\section{Figure 9}

\section{U.S. Exports of Chemicals to the World and by Trading Partner (2014)}

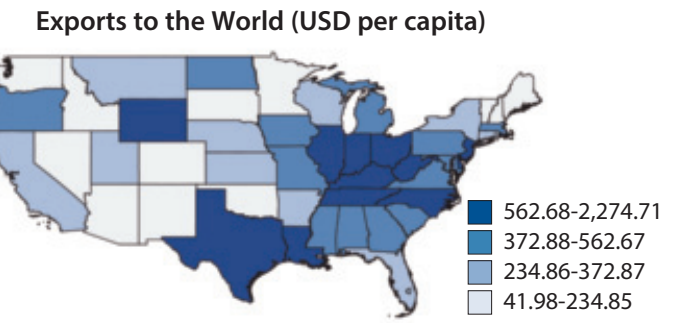

Exports to Mexico (USD per capita)

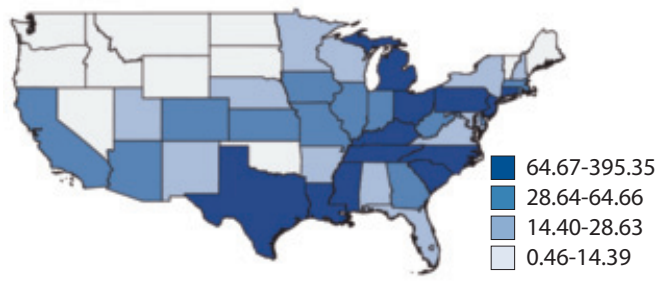

Exports to China (USD per capita)

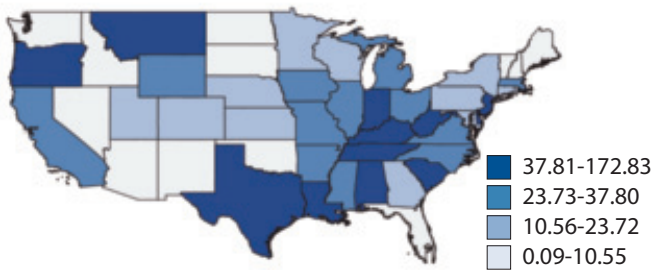

Exports to Canada (USD per capita)

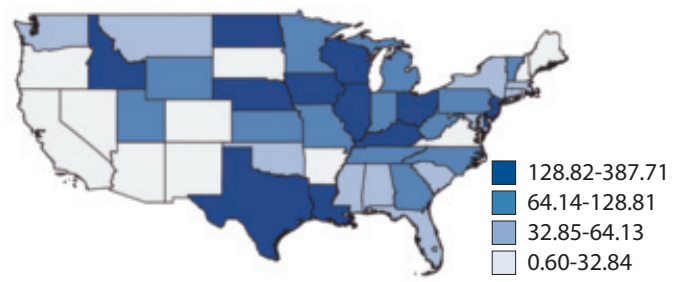

Exports to the European Union (USD per capita)

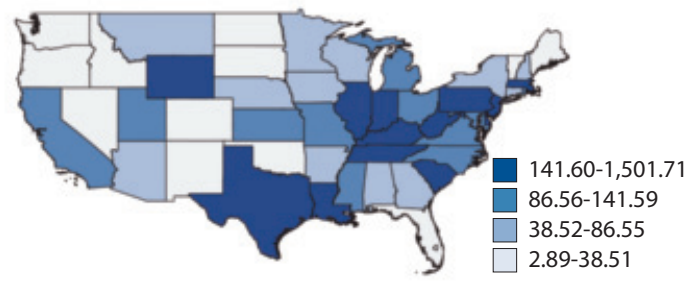

SOURCE: U.S. Census Bureau foreign trade statistics.

state exporters of computer and electronic products are in the same southwestern slice of the United States. The biggest per capita exporters of these products, however, were Vermont, Oregon, and Texas, at over $\$ 1,700$ each. Most states exported more computer and electronic products per capita to the EU than other trading partner. Exceptions included Texas and Vermont: Texas exported more computer and electronic products per capita to Mexico, at \$921, or \$24 billion overall, making Mexico the biggest recipient of these goods. Vermont exported more computer and electronic products per capita to Canada.

\section{Transportation Equipment}

Figure 12. On average, states imported $\$ 835$ per capita of transportation equipment in 2014. Most transportation imports were concentrated in a strip of states in the Midwest and Midsouth, from Michigan down to Mississippi, where a large portion of U.S. automobile production occurs. Michigan was the biggest per capita importer of transportation equipment, at over $\$ 7,000$, followed by Rhode Island and New Jersey, each above $\$ 2,000$. In regard to total 


\section{Dvorkin and Shell}

\section{Figure 10}

U.S. Imports of Computer and Electronic Products from the World and by Trading Partner (2014)

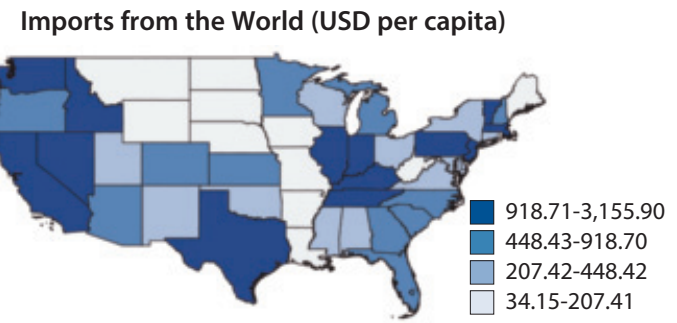

Imports from Canada (USD per capita)

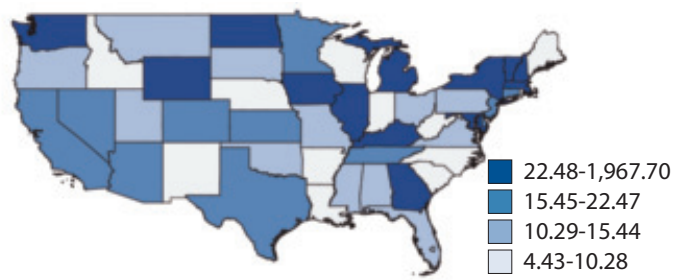

Imports from Mexico (USD per capita)

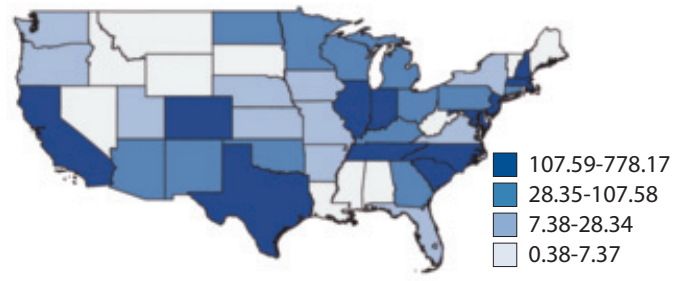

Imports from the European Union (USD per capita)

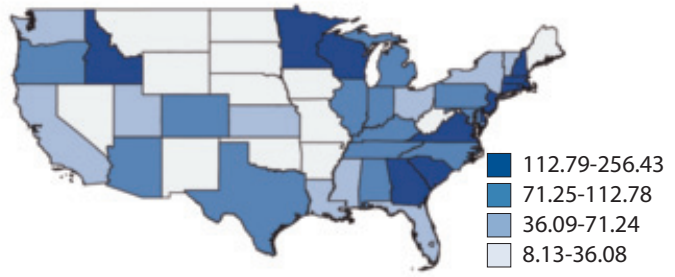

Imports from China (USD per capita)

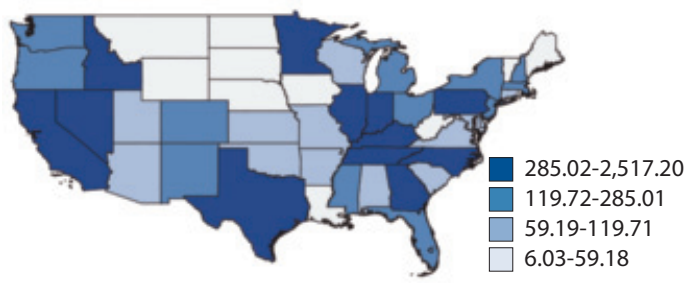

SOURCE: U.S. Census Bureau foreign trade statistics.

U.S. imports of transportation equipment, Mexico provided the most. At the per capita state level, imports came fairly evenly from the EU, Mexico, and Canada. Michigan imported approximately half of its transportation equipment from Mexico. Among states, Michigan was not only the biggest importer of these goods from Mexico, but also from Canada and China, while Rhode Island was the biggest importer of these goods from the EU.

Figure 13. On average, in 2014, states exported $\$ 749$ of transportation equipment per capita, with exports similarly concentrated in the auto-producing states, with the notable exception of Washington. Washington is actually the biggest per capita exporter of transportation equipment, most likely because of Boeing's large presence there. In 2014, Washington exported \$7,342 per capita of transportation goods, followed by Kentucky and Michigan, with closer to $\$ 3,000$ per capita each. As is the case for the nation, states exported the most transportation equipment to the EU and Canada, with Michigan sending more than any other state to Canada. Washington, however, actually sent most of its exports of transportation equipment to China. In terms of biggest trading partners, Canada and Mexico received most of 


\section{Figure 11}

\section{U.S. Exports of Computer and Electronic Products to the World and by Trading Partner (2014)}

Exports to the World (USD per capita)

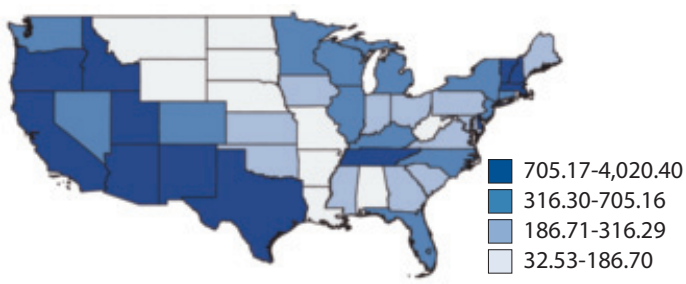

Exports to Mexico (USD per capita)

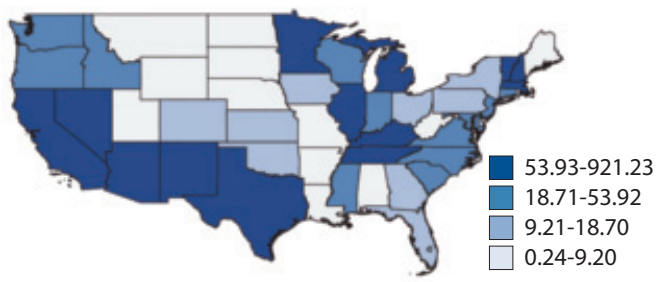

Exports to China (USD per capita)

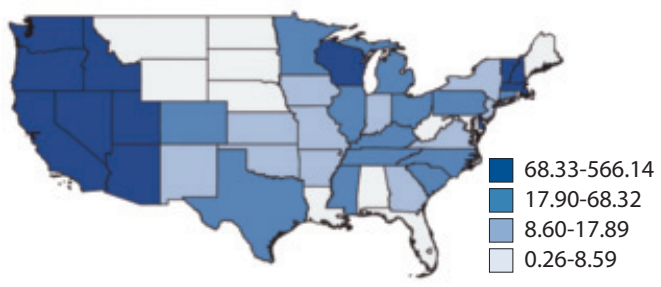

Exports to Canada (USD per capita)

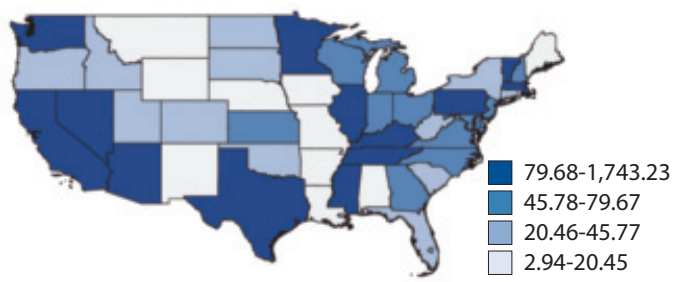

Exports to the European Union (USD per capita)

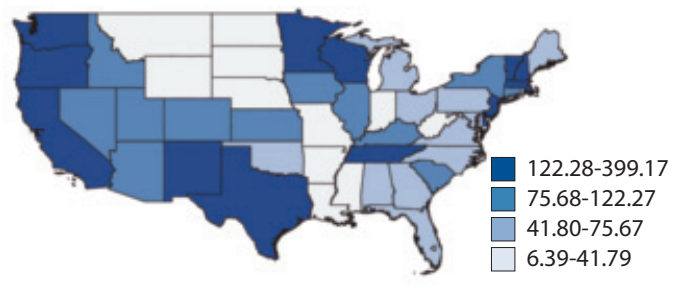

SOURCE: U.S. Census Bureau foreign trade statistics.

their U.S. transportation equipment from Michigan, China from Washington, and the EU from Connecticut.

\section{Machinery (Except Electrical)}

Figure 14. The geographic distribution of machinery imports and exports, respectively, in 2014 was similar to that of transportation equipment. On average, states imported $\$ 449$ per capita of machinery. Machinery imports seem to be slightly more sensitive to the geographic location of trading partners. Northern states imported more machinery from Canada, while southern states imported more from Mexico. The biggest per capita importers overall were North Dakota $(\$ 1,286)$, South Carolina $(\$ 1,175)$, and Kentucky $(\$ 985)$. On a per capita basis, the EU was the largest source of imports for most states. A few notable exceptions include North and South Dakota, which imported more machinery per capita from Canada. In terms of biggest trading partners, South Carolina imported the most machinery of any state from the EU and China, Kentucky from Mexico, and North Dakota from Canada. 


\section{Dvorkin and Shell}

\section{Figure 12}

\section{U.S. Imports of Transportation Equipment from the World and by Trading Partner (2014)}

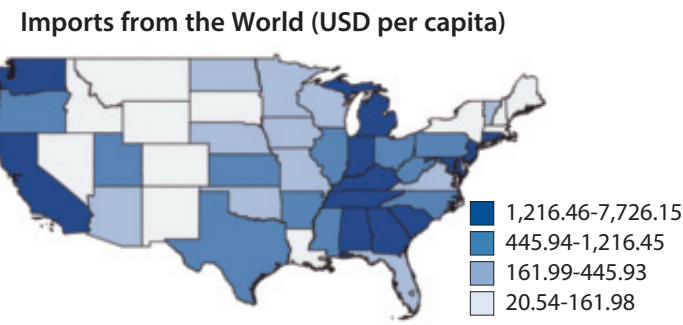

Imports from Canada (USD per capita)

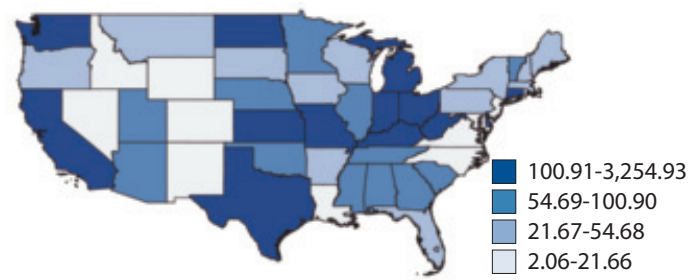

Imports from the European Union (USD per capita)

Imports from Mexico (USD per capita)
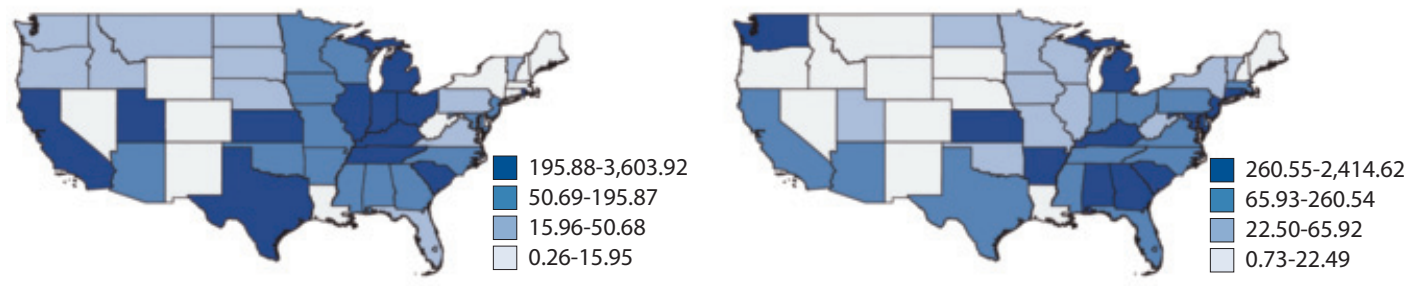

Imports from China (USD per capita)

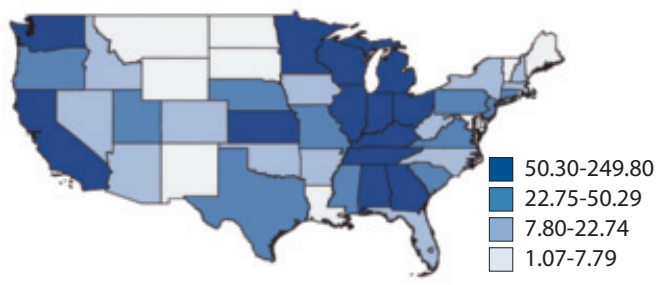

SOURCE: U.S. Census Bureau foreign trade statistics.

Figure 15. Exports of machinery in 2014 were somewhat concentrated in the northern Midwest and Texas. On average, states exported \$402 per capita of machinery. The biggest per capita exporters of machinery were North Dakota, Iowa, and Texas, at over $\$ 1,000$ per capita each. Most states sent the majority of their exports of machinery to Canada or the EU, although Texas sent the majority of its exports to Mexico. China received most of its U.S. machinery from Minnesota, the EU from Iowa, Mexico from Texas, and Canada from North Dakota.

\section{CONCLUSION}

The effects of globalization and international trade may be heterogeneous across industries and space. In this article, we performed a descriptive analysis of the geographic distribution of U.S. international trade in 2014. We looked particularly at which states exported and imported the most, the types of goods they traded, and their main trading partners. 


\section{Figure 13}

\section{U.S. Exports of Transportation Equipment to the World and by Trading Partner (2014)}

Exports to the World (USD per capita)

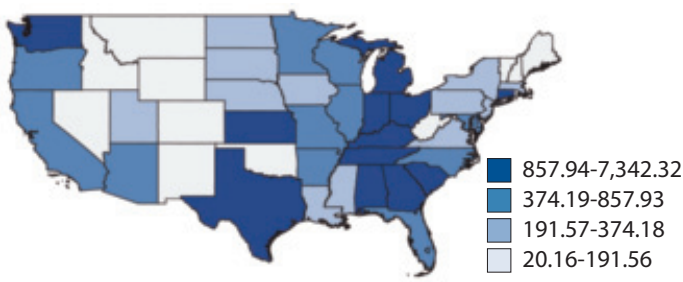

Exports to Mexico (USD per capita)

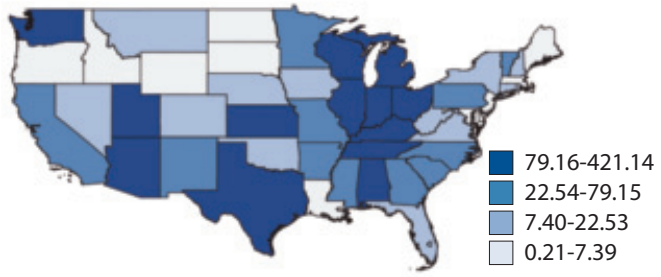

Exports to China (USD per capita)

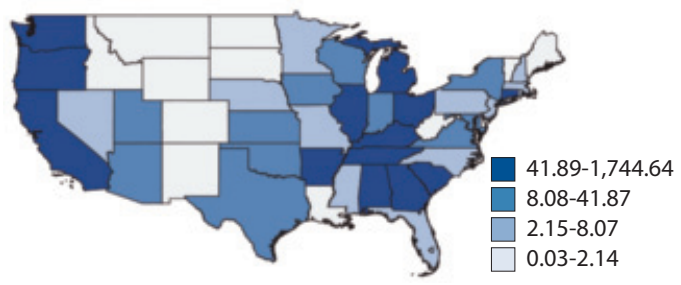

Exports to Canada (USD per capita)

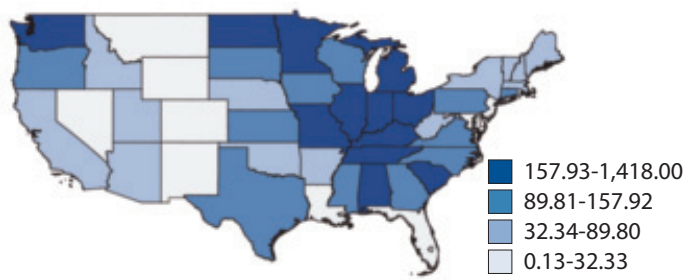

Exports to the European Union (USD per capita)

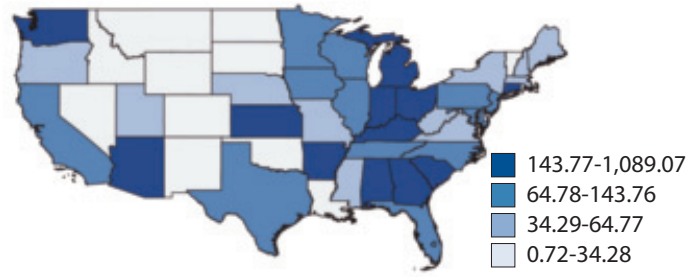

SOURCE: U.S. Census Bureau foreign trade statistics.

We found large regional dispersion in the origin and destination of U.S. international trade. We argue there are two important determinants of this pattern. First, proximity to trading partners influences trade volume, which is consistent with gravity models of international trade. Second, we also found that the heterogeneous spatial distribution of industries in the United States affects the concentration of exports and imports of individual states, which is consistent with the large intra-industry component of trade.

It is important to highlight some data limitations in our analysis. The trade data collected by the Census Bureau come directly from import and export records. Export data are reported through the Automated Export System and import data through the U.S. Customs and Border Protection's Automated Commercial System. Because the data are a direct account of goods and services flowing in and out of the United States, sampling error is not an issue. That being said, certain nonsampling errors can occur.

Many of the sources for nonsampling errors are typical of any dataset. The data are subject to reporting errors, undocumented (or illegal) shipments, and data-capture errors. There 


\section{Figure 14}

\section{U.S. Imports of Machinery (Except Electrical) from the World and by Trading Partner (2014)}

Imports from the World (USD per capita)

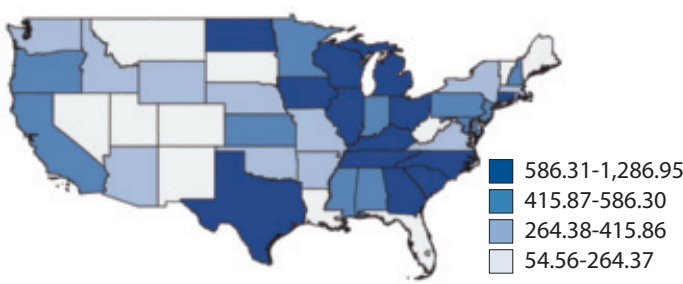

Imports from Mexico (USD per capita)

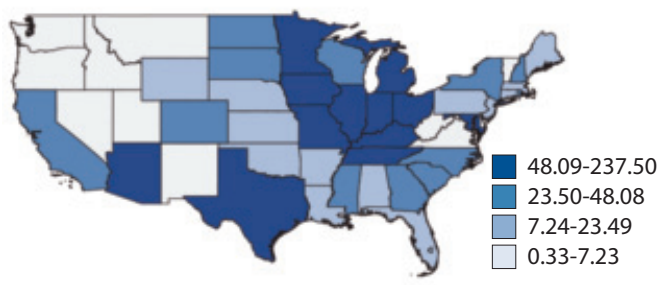

Imports from China (USD per capita)

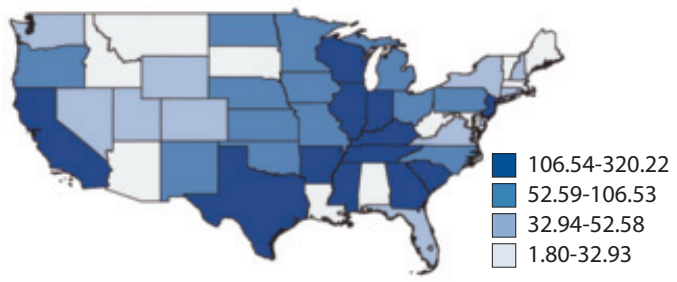

Imports from Canada (USD per capita)

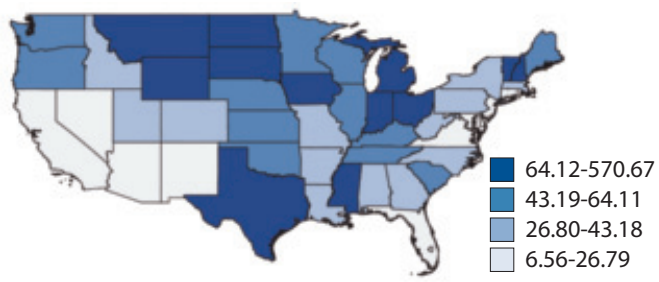

Imports from the European Union (USD per capita)

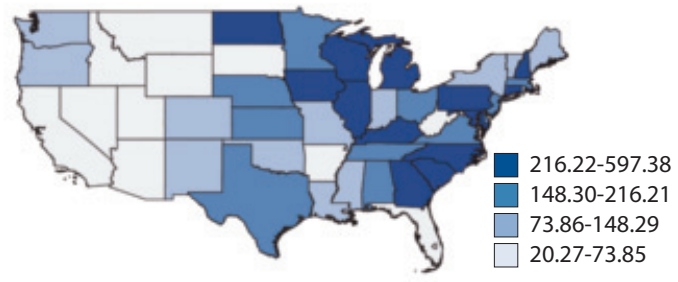

SOURCE: U.S. Census Bureau foreign trade statistics.

are, however, a few additional sources of nonsampling errors worth noting that are unique to the trade data. First, the United States does not require individual imports and exports valued below $\$ 2,000$ to be reported. To avoid omitting these data altogether, the Census Bureau estimates the annual amount of these "low-value" goods using country-specific factors. Because the amounts are estimated, estimation error is possible. However, the methodology was revised in 2010 and the Census Bureau regularly evaluates the methodology to make it more effective in identifying low-value trade.

Another source of nonsampling error particularly important for our state-level analysis is the potential misclassification in the origin of movement and state of destination. The statelevel export data are reported in terms of origin of movement, which means exports should be attributed to the state where they start their exportation journey (not the state with the actual exit port). However, if shipments are consolidated, which occurs when a freighter combines several individual shipments to fill space, it is possible the exports will all be attributed to the port state. These consolidated shipments can cause port-state exports to be overstated. 


\section{Figure 15}

\section{U.S. Exports of Machinery (Except Electrical) to the World and by Trading Partner (2014)}

Exports to the World (USD per capita)

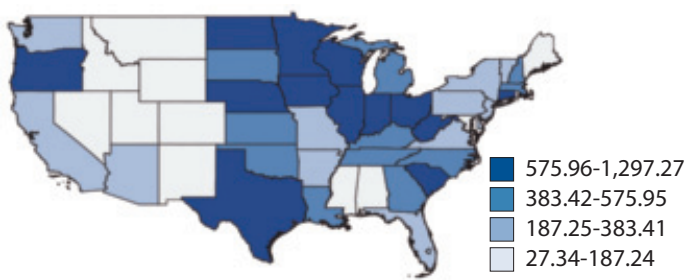

Exports to Mexico (USD per capita)

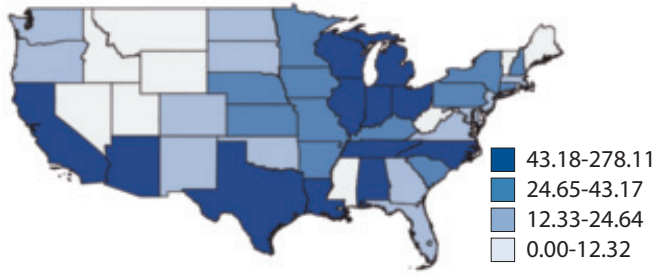

Exports to China (USD per capita)

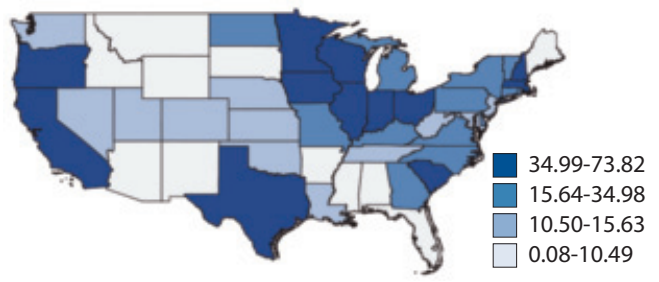

Exports to Canada (USD per capita)

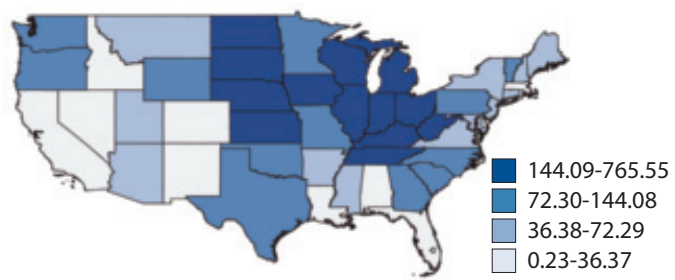

Exports to the European Union (USD per capita)

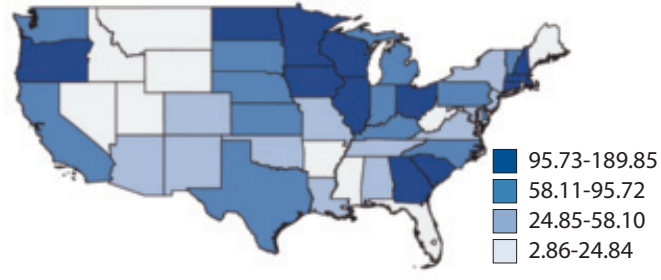

SOURCE: U.S. Census Bureau foreign trade statistics.

Overstatement is particularly common with agricultural exports shipped down the Mississippi River, with agricultural exports for Louisiana tending to be overstated.

Import data are recorded in terms of the state where the merchandise is destined (the state of destination). There are a few limitations with this form of import recording, similar to the export issues. First, if the shipments are consolidated, they are attributed to the state that receives the most. Such overstatement has less of a systematic bias than exports but could overstate imports in states where major trading companies are based. Additionally, if the state of destination is a storage or distribution point, the import destination may not reflect the state where the goods are consumed. For example, an importer of automobiles might import a large shipment that is meant to be distributed across the country. All the import value would be given to the company's home state as opposed to the states with distributing branches.

We are not aware of the magnitude of these misclassification errors or whether there is a generally accepted procedure to correct for them. In our analysis, we take the data at face value but recognize the potential pitfalls. 


\section{Dvorkin and Shell}

\section{NOTES}

1 The recent works by Autor, Dorn, and Hanson (2013) and Caliendo, Dvorkin, and Parro (2015) are examples of a nascent literature on this important topic.

2 The costs of moving goods across space, tariffs, and regulations also affect which goods and quantities thereof are traded.

3 When the EU is considered one trading partner, trade between the United States and the EU exceeds that between the United States and Japan; however, Japan is a larger trading partner than any individual country in the EU.

4 See, for example, Krugman (1979), Eaton and Kortum (2002), and Melitz (2003).

5 The early works of Grubel and Lloyd (1975) and Greenaway and Milner (1983) analyze the empirical patterns of trade across countries and find that most trade is intra-industry.

6 Similarly, states that trade more with China, Mexico, and Europe are mostly on the West Coast, in the South, and on the East Coast, respectively.

7 See Anderson (2011).

8 See Costinot and Rodriguez-Clare (2014) for a recent survey.

9 We use annual state population data from the Census Bureau population estimate program via Haver Analytics. Normalizing using state gross domestic product would slightly change the magnitudes reported here but would otherwise leave the (qualitative) results virtually unchanged.

${ }^{10}$ Although data for Hawaii and Alaska are included in our analysis, maps for these states are excluded from the figures.

${ }^{11}$ We include the EU in the analysis instead of its individual countries because it is a common trading bloc, with a common trade policy with other countries and non-trade barriers among its members. Countries comprising the EU are Austria, Belgium, Bulgaria, Croatia, Cyprus, Czech Republic, Denmark, Estonia, Finland, France, Germany, Greece, Hungary, Ireland, Italy, Latvia, Lithuania, Luxembourg, Malta, the Netherlands, Poland, Portugal, Romania, Slovakia, Slovenia, Spain, Sweden, and the United Kingdom.

12 The geographic and industry concentration of U.S.-Mexico trading is also influenced by maquila production. The maquiladora is a manufacturing operation whereby factories import foreign intermediate materials and equipment from a country free of duties or tariffs and then export the assembled, processed, and/or manufactured products mostly back to the country of origin of the raw materials. Data from the Banco de Mexico show that maquila-related trade accounted for almost 50 percent of all trade with Mexico in 2006, the bulk of which was with the United States. Most of these industries are located close to the U.S.-Mexico border.

${ }^{13}$ According to the World Input-Output Database (Timmer et al., 2015), in 2011, roughly 69 percent of U.S. imports were intermediate goods.

\section{REFERENCES}

Anderson, James E. "The Gravity Model." Annual Review of Economics, September 2011, 3(1), pp. 133-60.

Autor, David H.; Dorn, David and Hanson, Gordon H. "The China Syndrome: Local Labor Market Effects of Import Competition in the United States." American Economic Review, October 2013, 103(6), pp. 2121-68.

Caliendo, Lorenzo; Dvorkin, Maximiliano A. and Parro, Fernando. "Trade and Labor Market Dynamics." Working Paper No. 2015-009C, Federal Reserve Bank of St. Louis, August 2015; https://research.stlouisfed.org/wp/more/2015-009.

Costinot, Arnaud and Rodríguez-Clare, Andrés. "Trade Theory with Numbers: Quantifying the Consequences of Globalization," in Gita Gopinath, Elhanan Helpman, and Kenneth S. Rogoff, eds., Handbook of International Economics. Volume 4, Chap. 4. Oxford: Elsevier, 2014, pp. 197-261.

Eaton, Jonathan and Kortum, Samuel. "Technology, Geography, and Trade." Econometrica, September 2002, 70(5), pp. 1741-79. 
Greenaway, David and Milner, Chris R. "On the Measurement of Intra-Industry Trade." Economic Journal, December 1983, 93(372), pp. 900-08.

Grubel, Herbert G. and Lloyd, P.J. Intra-Industry Trade: The Theory and Measurement of International Trade in Differentiated Products. New York: Wiley \& Sons Inc., 1975.

Krugman, Paul R. "Increasing Returns, Monopolistic Competition, and International Trade." Journal of International Economics, November 1979, 9(4), pp. 469-79.

Melitz, Marc J. "The Impact of Trade on Intra-Industry Reallocations and Aggregate Industry Productivity." Econometrica, November 2003, 71(6), pp. 1695-725.

Timmer, Marcel P.; Dietzenbacher, Erik; Los, Bart; Stehrer, Robert and de Vries, Gaaitzen J. "An Illustrated User Guide to the World Input-Output Database: The Case of Global Automotive Production." Review of International Economics, August 2015, 23(3), pp. 576-605. 
